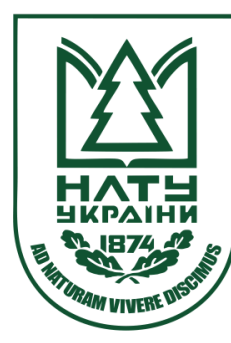

Науковий вісник НлТУ України

Scientific Bulletin of UNFU

ISSN 1994-7836 (print)

http://nv.nltu.edu.ua

https://doi.org/10.15421/40280509

Article received $22.05 .2018 \mathrm{p}$.

Article accepted 31.05.2018 p.

удк 674.031.632.22

$@ \bowtie$ Correspondence author

Yu. O. Rumiankov

rumyankovy@ukr.net

Ю. О. Рум'янков

Наиіональний дендрологічний парк "Софіївка" НАН України, м. Умань, Україна

\title{
МОНОСАДИ ВИДІВ ТА ФОРМ БУКА (FAGUS L.) В НАЦІОНАЛЬНОМУ ДЕНДРОЛОГІЧНОМУ ПАРКУ "СОФІЇВКА" НАН УКРАЇНИ
}

Проаналізовано історію інтродукції видів та форм бука в дендропарку "Софіївка" НАН України. Визначено, що паркові насадження моносаду буків локалізовані по території парку в 16-ти кварталах. Проаналізовано дендрологічну структуру насаджень бука в моносадах дендропарку. Наведено основні зосередження букових насаджень, такі як колекційна та експозиційна ділянки, найбільші чисті насадження $F$. sylvatica та алейні посадки. Надано кількісну характеристику видів та форм бука на території дендропарку поквартально. Виявлено найменш поширені форми бука в дендропарку, які внесено до списку запланованих посадок. На основі інвентаризаційних досліджень складено картосхему розміщення моносаду видів та форм бука. Визначено, що вікова структура видів та форм бука в Національному дендрологічному парку "Софіївка" представлена більшою мірою молодими рослинами прегенеративного віку, ніж віковими деревами. Оцінено фітосанітарний стан дерев букового моносаду, їх стан визначено як мало ослаблені (І група). Виявлено можливість весняного враження молодих рослин бука тлею з родини Aleyrodidae Westwood (Білокрилки). Якість стану дерев бука в насадженнях парку оцінено як добрий. У насадженнях окремих кварталів виявлено перезагущення деревостану, що знижує його якість до задовільного стану. Надано рекомендації щодо оптимізації паркової структури моносадів бука та покращення їх естетики сприйняття. На основі проведених досліджень створено зведений каталог видів та форм бука в моносадах НДП "Софіївка" НАН України.

Ключові слова: паркове насадження бука; історія; структура; стан якості деревостану; оптимізаціям.

Вступ. Національний дендрологічний парк "Софіївка" НАН України створено в романтичному стилі з використанням штучно створених ландшафтів та регулярних композицій з рослин. 3 усієї маси деревних композицій в парку можна виділити насадження одного виду чи роду. Створені свого часу насадження видів і форм бука в Національному дендрологічному парку "Софіївка" можна розглядати як окрему структурну одиницю під назвою "моносад". Тепер постало питання щодо принципів збереження та догляду наявних насаджень видів і форм буків у моносадах дендрологічного парку "Софіївка".

Тому мета дослідження - проаналізувати історію інтродукції видів та форм бука в дендропарку "Софіївка" НАН України, визначити локалізацію деревостану, дендрологічну та вікову структуру, фітосанітарний стан дерев та надати рекомендації щодо оптимізації паркової структури моносаду та покращення естетики його сприйняття.

Матеріали і методи дослідження. Об'єкт нашого дослідження - паркові насадження видів та форм бука в Національному дендрологічному парку "Софіївка" НАН України. Предмет дослідження - історія інтродукції, вікова та дендрологічна структура, локалізація та якість стану моносаду бука.

Під час виконання інвентаризаційних робіт використовували методичні вказівки до проведення польових робіт з інвентаризації лісів Поліського регіону України 2006 р., методичні рекомендації з інвентаризації, таксації та моніторингу багаторічних насаджень в історичних парках України (Kosenko et al., 2014). Обстеження вікових дерев виконували за рекомендаціями А. І. Кушніра (Kushnir et al., 1995). Категорії фітосанітарного стану дерев оцінювали за шкалою Н. П. Красинського у модифікації Ю. З. Кулагіна (Tarabrin et al., 1986).

Результати дослідження та їх обговорення. У Національному дендропарку "Софіївка" інтродукція видів i форм бука розпочалась з 1892 p. (Reva, 1963), коли В. В. Пашкевич заклав "Англійський парк", де було посаджено Fagus sylvatica L., F. s. 'Atropunicia', F. s. 'Quercifolia', $F$. s. 'Rotundifolia'. Саме тоді, на нашу думку, було посаджено і F. orientalis Lipcky в районі "Слисейських полів".

У 1991 р. дерево F. orientalis загинуло від пошкодження стовбуровою гниллю. Наразі в парку зростають дерева F. orientalis, які вирощені з насіння, привезеного 3 Тебердинського заповідника у 1991 p. (Kozlov, 2000).

Унаслідок експедиційних досліджень за участі Козлова Володимира Георгійовича в 1987-1991 рр. та моніторингу зелених насаджень у Вінницькій, Черкаській, Хмельницькій, Закарпатській, Львівській і Київській областях, а також в ботанічних садах Санкт-Петербурга, Таллінна, Риги, Мінська, Калінінграда, Вільнюса, Каунаса; парків та розсадників у Польщі - у Варшаві,

\section{Інформація про авторів:}

Рум'янков Юрій Олегович, канд. біол. наук, наук. співробітник. Email: rumyankovy@ukr.net

Цитування за ДСту: Рум'янков Ю. О. Моносади видів та форм бука (Fagus L.) в національному дендрологічному парку "Софіївка" НАН України. Науковий вісник НЛТУ України. 2018, т. 28, № 5. С. 44-48.

Citation APA: Rumiankov, Yu. O. (2018). Monogardens of species and forms of beech (Fagus L.) in the national dendrological park

"Sofiyivka" of the National academy of sciences of Ukraine. Scientific Bulletin of UNFU, 28(5), 44-48.

https://doi.org/10.15421/40280509 
Курніку, Рогатині та ін. було виявлено та інтродуковано у дендропарк "Софіївка" нові види та форми бука.

Табл. 1. Історія інтродукції видів та форм бука в дендропарку "Софіївка" НАН України 31891 по 2017 рр.

\begin{tabular}{|c|c|c|c|c|c|c|c|c|c|}
\hline \multirow[b]{2}{*}{ Вид та форма бука } & \multicolumn{9}{|c|}{ Рік інтродукції } \\
\hline & $\begin{array}{l}\bar{\infty} \\
\text { } \\
\circ\end{array}$ & 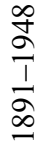 & 훙 & $\widehat{\circ}$ & $\stackrel{\circ}{2}$ & $\begin{array}{l}\infty \\
\infty \\
\infty\end{array}$ & $\stackrel{\circ}{\stackrel{\circ}{\varrho}}$ & ஓ & $\frac{1}{\sigma}$ \\
\hline 1. Fagus grandifolia Ehrh. & & & & & & + & + & + & 1 \\
\hline 2. Fagus orientalis Lipsky & + & + & + & + & + & + & + & + & + \\
\hline 3. Fagus sylvatica $\mathrm{L}$. & & + & + & + & + & + & + & + & + \\
\hline 4.F. $s .{ }^{\prime}$ Aspl & & & & & + & + & + & + & + \\
\hline 5. F.s. 'Atro & & + & + & + & + & + & + & + & + \\
\hline 6. F.s. 'Fastigiata' & & & & & + & + & + & + & + \\
\hline 7. F. s. 'Purpurea Fastigiata' & & & & & + & + & + & + & + \\
\hline 8. F. s. 'Pendula' & & & & & + & + & + & + & + \\
\hline 9. F.s. 'Que & & + & & & & & & & + \\
\hline 10.F.s. 'Rohanii' & & & & & & & & + & + \\
\hline 11. F. s. 'Roseo-marginata' & & & & & + & + & + & + & + \\
\hline $\begin{array}{l}\text { 12. Fagus sylvatica 'Rotun- } \\
\text { difolia' }\end{array}$ & & + & + & + & + & + & + & + & + \\
\hline 13. F. s. ' $\mathrm{Cu}$ & & & & & & & & & + \\
\hline 14. F. s. 'Zlatia' & & & & & & + & + & + & + \\
\hline
\end{tabular}

Виявлено, що з 1891 по 1987 рр. кількість таксонів бука збільшилась у 2 рази, а по 1991 р. - у 3 рази (табл. 1). У міру збагачення колекційного фонду, нові форми бука було застосовано в декоративному озелененні ділянок парку. Отже, видове та формове різноманіття буків у Національному дендрологічному парку "Софіївка" НАНУ на 2017 р. становить 14 таксонів.

Паркові насадження моносаду видів та форм бука локалізовані по території парку в 16-ти кварталах. Найбільше зосередження букових насаджень - це колекційні ділянки у кварталі № 1 (рис.), експозиційна ділянка у кварталі № 14, великі чисті насадження $F$. sylvatica у кварталах № 4 та 7, алейні посадки $F$. sylvatica у кварталах № 19 та 20 та куртини $F$. sylvatica у кварталі № 27.

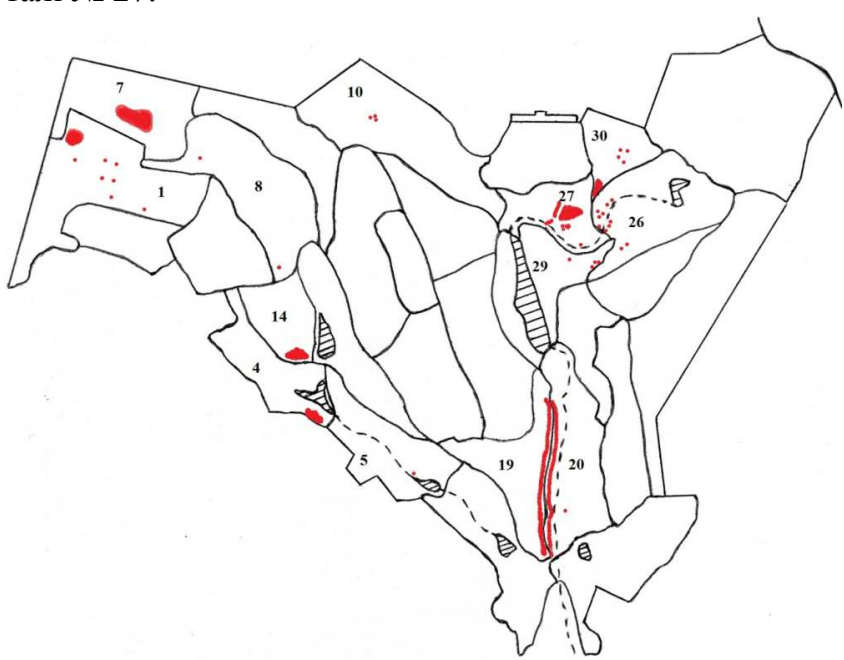

Рисунок. Розміщення моносаду буків у Національному дендрологічному парку "Софіївка" НАНУ

Загальна кількість дерев видів та форм бука в Національному дендрологічному парку "Софіївка" НАНУ 845 шт., серед них найпоширеніший вид $F$. sylvatica633 дерева, що становить найбільшу частку в структурі парку $-74,9 \%$. Кількість дерев видів $F$. orientalis та $F$. grandifolia набагато менша - 14 та 18 відповідно (табл. 2). Формове різноманіття F. sylvatica в дендропарку нараховує 181 дерево. Найбільша кількість серед щеплених форм бука $-F . s$. 'Atropunicea' та $F$. s. 'Fastigiata' - 37 та 34 шт. відповідно. Найменша кількість $F . s$. 'Cuprea' та F. s. 'Rohanii' - 3 та 2 шт. відповідно.

Табл. 2. Загальна кількість дерев видів та форм бука в Національному дендрологічному парку "Софіївка" НАНУ на 2017 p.

\begin{tabular}{|c|c|c|}
\hline Назва виду або форми & $\begin{array}{l}\text { Кількість } \\
\text { дерев, шт. }\end{array}$ & $\begin{array}{c}\text { Частка від загальної } \\
\text { кількості дерев бу- } \\
\text { ка, \% }\end{array}$ \\
\hline F. sylvatica L. & 633 & 74,9 \\
\hline F. grandifolia Ehrh. & 18 & 2,1 \\
\hline F. orientalis Lipsky & 13 & 1,5 \\
\hline F. s. 'Asplenifolia' & 8 & 0,9 \\
\hline F. s. 'Atropunicea' & 38 & 4,5 \\
\hline F.s. 'Fastigiata' & 34 & 4 \\
\hline F.s. 'Purpurea Fastigiata' & 5 & 0,6 \\
\hline F. s. 'Pendula' & 30 & 3,5 \\
\hline F. s. 'Quercifolia' & 8 & 0,9 \\
\hline F.s. 'Rohanii' & 2 & 0,2 \\
\hline F. s. 'Roseo-marginata' & 13 & 1,5 \\
\hline F.s. 'Rotundifolia' & 17 & 2 \\
\hline F.s. 'Cuprea' & 3 & 0,35 \\
\hline F.s. 'Zlatia' & 23 & 2,7 \\
\hline $\begin{array}{l}\text { Загальна кількість дерев } \\
\text { бука }\end{array}$ & 845 & 100 \\
\hline
\end{tabular}

У кварталах № 4, 7, 19, 20 та 38 утримуються чисті насадження $F$. sylvatica, найбільша їх кількість зосереджена у кварталах № 4 та 7-122 та 204 дерева відповідно (табл. 3). Виявлено, що формове різноманіття бука найбільше представлено в кварталах № 1 та 14. У кварталі № 1 розташована колекційна ділянка, де власне виконуємо розмноження форм бука шляхом щеплення, частка яких в загальній структурі становить $21 \%$.

У кварталі № 14 створено моносад буків, де продемонстровано найбільшу кількість форм бука для відвідувачів парку, частка яких у загальній структурі становить $4 \%$. Варто виділити види та форми бука, які недостатньо поширені у паркових композиціях. Це $F$. grandifolia - тільки 2 шт., $F . s$. 'Asplenifolia' - 1 шт., $F$. $s$. 'Fastigiata' - 4 шт., F. s. 'Purpurea Fastigiata' - 1 шт., $F . s$. 'Pendula' - 3 шт., F. s. 'Quercifolia' - 2 шт., F. s. 'Roseomarginata' - 2 шт., F. s. 'Cuprea' - 3 шт., F. s. 'Zlatia' 1 шт., F. s. 'Rohanii' - жодного. Названі види та форми бука рекомендуємо до запланованих посадок на нових територіях.

Табл. 3. Дендрологічна структура видів та форм бука поквартально

\begin{tabular}{|c|c|c|c|}
\hline $\begin{array}{c}\text { № } \\
\text { кварталу }\end{array}$ & $\begin{array}{c}\text { Кількість } \\
\text { таксонів, шт. }\end{array}$ & $\begin{array}{c}\text { Кількість } \\
\text { дерев, шт. }\end{array}$ & $\begin{array}{c}\text { Частка дерев у } \\
\text { кварталі від за- } \\
\text { гальної кількості } \\
\text { дерев бука, \% }\end{array}$ \\
\hline 1 & 14 & 177 & 20,9 \\
\hline 4 & 2 & 123 & 14,5 \\
\hline 5 & 1 & 1 & 0,1 \\
\hline 7 & 1 & 204 & 24,1 \\
\hline 8 & 1 & 2 & 0,2 \\
\hline 10 & 1 & 3 & 0,3 \\
\hline 14 & 10 & 35 & 4,1 \\
\hline 19 & 1 & 43 & 5,0 \\
\hline 20 & 2 & 90 & 10,6 \\
\hline 26 & 3 & 11 & 1,3 \\
\hline 27 & 2 & 97 & 11,5 \\
\hline 29 & 3 & 5 & 0,6 \\
\hline 30 & 4 & 16 & 1,9 \\
\hline 38 & 1 & 23 & 2,7 \\
\hline 39 & 3 & 14 & 1,6 \\
\hline
\end{tabular}

Scientific Bulletin of UNFU, 2018, vol. 28, no 5 
Вікова структура видів та форм бука в Національному дендрологічному парку "Софіївка" представлена досить широко. Найстарші дерева бука ростуть на ділянці "Ангійський парк" вже понад 100 років. Це три дерева, які було посаджено в 1892 р.: F. sylvatica, F. s. 'Rotundifolia' та $F$. s. 'Atropunicea'. Масова частка 100-річних дерев - 0,3 \% (табл. 4). Дерева 100-річного віку мають діаметр стовбура $66^{ \pm 9}$ см та заввишки $-30^{ \pm 3} \mathrm{M}$.

Дерева 50-річного віку в загальній кількості 34 дерева посаджено в 1967 р.: це 8 дерев F. orientalis, які ростуть на території арборетуму дослідно-виробничої ділянки розсадника. Три 50-річних дерева $F$. sylvatica ростуть у балці "Звіринець". Дерева в гарному стані. Плодоносять, але насіння плюскле. У кварталі № 38 "Правий південний берег Війтівського (третього) ставка" росте 23 дерева, які посаджено також у 1967 р. Масова частка 50-річних дерев - 4 \%. Дерева 50-річного віку мають діаметр стовбура $46^{ \pm 21} \mathrm{~cm}$ та заввишки $17^{ \pm 5}$ M.

Табл. 4. Вікова структура видів та форм бука в Національному дендрологічному парку "Софї̈вка" НАНУ

\begin{tabular}{|c|c|c|}
\hline Рік посадки & $\begin{array}{c}\text { Кількість дерев, } \\
\text { шт. }\end{array}$ & $\begin{array}{c}\text { Частка дерев від загальної } \\
\text { кількості дерев бука, \% }\end{array}$ \\
\hline 1892 & 3 & 0,3 \\
\hline 1967 & 34 & 4 \\
\hline 1981 & 11 & 1,3 \\
\hline $1987-1989$ & 207 & 24,5 \\
\hline 1991 & 2 & 0,2 \\
\hline 1996 & 123 & 14,5 \\
\hline 1998 & 4 & 0,5 \\
\hline $2000-2017$ & 459 & 54,3 \\
\hline
\end{tabular}

Дерева 36-річного віку в загальній кількості 11 дерев посаджено 1981 р.: це 5 дерев $F$. sylvatica та одне дерево $F$. s. 'Atropunicea' у кварталі № 39 в арборетумі виробничо-дослідного розсадника; три дерева $F$. sylvati$c a$ та одне дерево $F$. s. 'Cuprea' у кварталі № 26 "Слисейські поля" біля містка рослин, також одне дерево $F$. sylvatica в кварталі № 8 "Центральна частина Грекової балки" західна частина, правий схил. Масова частка 36річних дерев - 1,3\% Дерева 36-річного віку мають діаметр стовбура $32,5^{ \pm 17}$ см та заввишки - $14,5^{ \pm 4,5}$ м.

Дерева 28-30-річного віку в загальній кількості 207 дерев посаджено в 1987-1989 рр.: це одне дерево $F$. sylvatica у кварталі № 1 біля воріт в'їзду на ПТО, одне дерево $F$. s. 'Asplenifolia' у кварталі № 4, одне дерево $F$. $s$. 'Atropunicea' у кварталі № 20 "Мала Швейцарія" та 204 дерева $F$. sylvatica у кварталі № 7 на правому схилі вершини Грекової балки. Масова частка 28-30-річних дерев - 24,5 \% Дерева 28-30-річного віку мають діаметр стовбура $24,5^{ \pm 20,5} \mathrm{~cm}$ та заввишки $-11,5^{ \pm 6,5} \mathrm{M}$.

Дерева 26-річного віку посаджено в 1991 р.: два $F$. orientalis ростуть у кварталі № 26 біля пам'ятника "Природа і мистецтво". Масова частка 26-річних дерев0,2 \%. Дерева 26-річного віку мають діаметр стовбура $30,5^{ \pm 3,5}$ см та заввишки $-12^{ \pm 0,7}$ м.

Дерева 21-річного віку в загальній кількості 123 дерева посаджено в 1996 р.: одне дерево $F$. sylvatica росте у кварталі № 29 "Кавказька гірка" між кам'яним містком та павільйоном Флори та 122 дерева цього ж виду - у кварталі № 4 "Лебединий став". Масова частка 21річних дерев - 14,5 \%. Дерева 21-річного віку мають діаметр стовбура $16,5^{ \pm 9,5}$ см та заввишки $-10,5^{ \pm 2,5}$ м.

Дерева 19-річного віку ростуть на ділянці'Старий готель" у кварталі № 1: F. s. 'Fastigiata', F. s. 'Pendula', F. sylvatica та $F$. s. 'Rohanii' - по одному дереву кожного, посаджено в 1998 році. Масова частка 19-річних дерев - 0,5\%. Дерева 19-річного віку мають діаметр стовбура $9,5^{ \pm 4,5}$ см та заввишки $-6^{ \pm 2}$ м.

За останні 17 років за період з 2000 по 2017 рр. було посаджено 459 дерев бука: це 334 дерев $F$. sylvatica; 23 дерева $F . s$. 'Zlatia', які ростуть загалом на ділянці щеплених форм, одне 3 яких росте в моносаду в кварталі № 14 "Греків кряж"; два $F$. s. 'Cuprea' - на території адміністративної зони; 16 дерев $F$.s. 'Rotundifolia', які ростуть на ділянці щеплених форм та в кварталі № 14; 13 дерев $F$. s. 'Roseo-marginata', які ростуть на ділянці щеплених форм та в кварталі № 14; тільки одне дерево $F$. s. 'Rohanii' на ділянці щеплених форм; 8 дерев $F$. s. 'Quercifolia', які ростуть на ділянці щеплених форм та в кварталі № 14, та одне 3 них в Англійському парку; 29 дерев $F$. s. 'Pendula'; 5 дерев $F$. s. 'Purpurea Fastigiata', які ростуть на ділянці щеплених форм та в кварталі №14; 7 дерев $F$. s. 'Asplenifolia', які ростуть на ділянці щеплених форм, 3 дерева $F$. orientalis у кварталі № 29; 18 дерев $F$. grandifolia, які ростуть загалом на ділянці щеплених форм, два з яких в кварталі № 14 та одне біля службового входу в корпус адміністративної будівлі. Масова частка дерев, посаджених за останні 17 років, становить 54,3\%.

Отже, найбільша частка видів та форм бука в НДП "Софіївка" - це дерева віком до 17 років, яка становить 54 \% від дендроструктури моносаду.

За фітосанітарним станом деревні насадження поділяють на 7 груп (Tarabrin et al., 1986). Головні фактори розподілу - кількість сухих гілок, ажурність та зрідженість крони, річний приріст; механічні, вірусні та грибкові пошкодження, а також наявність водяних пагонів. Оцінюючи фітосанітарний стан буків, варто відзначити гарну ажурну крону, повноцінні дві хвилі річного приросту, відсутність механічних, вірусних чи грибкових ушкоджень, а також водяних пагонів. Лише на молодих ослаблених рослинах, у рік їх пересадки на нове місце, на листках навесні з'являється тля 3 родини Aleyrodidae Westwood (Білокрилки). Тому оцінюємо фітосанітарний стан дерев букового моносаду як мало ослаблені (I група).

Якісний стан дерев оцінюють за трьома градаціями як добрий, задовільний та незадовільний (Kosenko et al., 2014). Оцінюючи стан дерев бука в новостворених насадженнях, з'ясовано, що дерева здорові, нормально розвинені, листя густе та рівномірно розміщене на гілках, листя нормального розміру та забарвлення, немає ознак хвороб та шкідників, немає пошкоджень стовбура та скелетних гілок, немає дупел. Отже, якість стану дерев буків оцінено як добрий. Виявлено високу загущеність посадок віком понад 10 років у кварталах № 27 та № 30, а тому рекомендуємо вчасне проріджування посадок, щоб уникнути витягування стовбура та відсихання гілок нижнього ярусу.

Оцінюючи стан дерев у чистих насадженнях бука лісового віком 20-30 років в кварталах № 4 та 7, виявлено перезагущення деревостану та як наслідок - появу сухих гілок у нижньому ярусі, нерівномірно розвинену та зріджену крона та непропорційно витягнутий стовбур. Тому оцінка стану дерев у чистих насадженнях бука лісового в кварталах № 4 та 7 задовільна.

Проаналізувавши дендрологічну структуру насаджень бука, їх фітосанітарний стан та клас якості, нада- 
но рекомендації щодо оптимізації паркової структури моносадів буків та покращення їх естетики сприйняття:

1. Враховуючи недостатню кількість формового різноманіття $F$. sylvatica в дендрологічній структурі парку потрібно провести відповідні посадки, що сприятиме збільшенню масштабу моносаду та покращить його структуру.

2. Виконати прорідження деревостану в чистих насадженнях F. sylvatica кварталу № 4, а також протягом року прорідити посадки у кварталах № 27 та 30 для уникнення витягування стовбура та відсихання гілок та непропорційного розвитку крони.

На основі проведених досліджень створено зведений каталог моносаду видів і форм бука в НДП "Софіївка", який має табличний вигляд та його аналог у текстовому варіанті, де наведено локалізацію та кількість дерев поквартально, дендрологічну та вікову структуру посадок, а також біометричні показники, схему посадки та санітарний стан деревостану.

\section{Висновки:}

1. Загальна кількість дерев видів та форм бука в Національному дендрологічному парку "Софіївка" НАНУ 845 шт., серед них найпоширеніший вид $F$. sylvatica 633 дерева, які зосереджені у вигляді чистих насаджень у кварталах № 4 та 7, алейних посадок у кварталах № 19 та 20 та групових - у кварталі № 27. Формове різноманіття F. sylvatica в НДП "Софіївка" на 2017 р. нараховує 181 дерево, що становить 14 таксонів. Найбільша кількість щеплених форм $F$. sylvatica на колекційній ділянці в кварталі № 1 та експозиційній ділянці в кварталі № 14.

2. Вікова структура видів та форм бука в Національному дендрологічному парку "Софіївка" представлена досить широко: 3 сторічних дерева, 34-50-річних, 11-36- річних, 207 дерев - 30-річних, 2-26-річних, 123-21-річних, 4-19-річних, решта 459 дерев посаджено за останні 17 років. Найбільша частка видів та форм бука в НДП "Софіївка" - це дерева віком до 17 років, які становлять 54 \% від дендроструктури моносаду.

3. Фітосанітарний стан дерев букового моносаду оцінено як мало ослаблені (І група). Якісний стан дерев видів та форм бука в НДП "Софіївка" оцінено як добрий. Оцінка стану дерев в чистих насадженнях $F$. sylvatica кварталів № 4 та 7 задовільна.

4. Створено зведений каталог моносаду видів та форм бука в НДП "Софіївка".

\section{Перелік використаних джерел}

Kosenko, I. S., Graboviy, V. M., \& Muzika, G. I. (2014). Metodichni rekomendatsiyi $z$ inventarizatsiyi, taksatsiyi ta monitoringu bagatorichnih nasadzhen $v$ istorichnih parkah Ukrayini. Uman: VPTs "Vizavi" (Vidavets "Sochinskiy"), 64 p. [In Ukrainian].

Kozlov, V. H. (2000). Formuvannia kolektsii vydiv i kultyvariv buka v dendroparku "Sofiivka" NAN Ukrainy. Introduktsiia roslyn, 2, 84-87. [In Ukrainian].

Kushnir, A. I., Sirenko, I. P., \& Yukhymets, A. I. (1995). Znamenyti ta istorychni dereva Ukrainy: pershi pidsumky vyvchennia. Oikumena. Ukrainskyi ekolohichnyi visnyk, 1-2, 158-159. [In Ukrainian].

Poliska. (2006). Metodichni vkazivki do provedennia polovikh robit z inventarizatcii lisiv Poliskogo regionu Ukraini. Irpin, 74 p. [In Ukrainian].

Reva, M. L. (1963). 70 rokiv arboretumu V. V. Pashkevycha u dendroparku "Sofiivka". Pytannia biolohii aklimatyzovanykh roslyn, (pp. 9-16). Kyiv: Vyd-vo AN USSR. [In Ukrainian].

Tarabrin, V. P., Kondratiuk, E. N., Bashkatov, V. G., et al. (1986). Fitotoksichnost organicheskikh $i$ neorganicheskikh zagriaznitelei. Kyiv: Naukova dumka, 216 p. [In Russian].

Ю. О. Румянков

Национальный дендрологический парк "Софиевка", НАН Украины, г. Умань, Украина

\section{МОНОСАДЫ ВИДОВ И ФОРМ БУКА (FAGUS L.) В НАЦИОНАЛЬНОМ ДЕНДРОЛОГИЧЕСКОМ ПАРКЕ "СОФИЕВКА" НАН УКРАИНЫ}

Проанализирована история интродукции видов и форм бука в Национальном дендропарке "Софиевка" НАН Украины. Определено, что парковые насаждения моносада буков локализованы по территории парка в 16-ти кварталах. Проанализирована дендрологическая структура насаждений бука в моносадах дендропарка. Указаны основные сосредоточения буковых насаждений, такие как коллекционный и экспозиционный участки, чистые насаждения $F$. sylvatica и его аллейные посадки. Предоставлена количественная характеристика видов и форм бука на территории дендропарка поквартально. Выявлены наименее распространенные формы бука в дендропарке, которые внесены в список запланированных посадок. На основе инвентаризационных исследований составлена картосхема размещения моносадов видов и форм бука. Определено, что возрастная структура видов и форм бука в Национальном дендрологическом парке "Софиевка" представлена в большей степени молодыми растениями прегенеративного возраста. Проведена оценка фитосанитарного состояния деревьев буковых моносадов, их состояние определено как мало ослабленные (І группа). Выявлена возможность весеннего поражения молодых растений бука тлей из семейства Aleyrodidae Westwood (Белокрылки). Качество состояния деревьев бука в насаждениях парка оценено как хорошее. В насаждениях отдельных кварталов обнаружено чрезмерное уплотнение древостоя, что снижает его качество до удовлетворительного состояния. Предоставлены рекомендации по оптимизации парковой структуры моносадов бука и улучшения их эстетики восприятия. На основе проведенных исследований создан сводный каталог видов и форм бука в моносадах НДП "Софиевка" НАН Украины.

Ключевые слова: насаждения бука; история; структура; состояние качества древостоя; оптимизация.

Yu. O. Rumiankov

National Arboretum "Sofiyivka", NAS Ukraine, Uman, Ukraine

\section{MONOGARDENS OF SPECIES AND FORMS OF BEECH (FAGUS L.) IN THE NATIONAL DENDROLOGICAL PARK "SOFIYIVKA" OF THE NATIONAL ACADEMY OF SCIENCES OF UKRAINE}

Once created planting species and forms of beech in the National Dendrological Park "Sofiyivka" of the National Academy of Sciences of Ukraine we can consider as a separate structural unit called monogarden. In order to determine the principles of preservation and care of existing plantations, we needed to perform monitoring surveys. Therefore, the purpose of our study was to analyze the history of introduction of species and forms of beech in the Park "Sofiyivka" of the National Academy of Sciences of Ukraine, determine the localization of the tree stand, the dendrological and age structure of species and forms of beeches, the phytosanitary state of trees and provide recommendations for optimizing the park structure of beech monogarden and improve the 
aesthetics of its perception. We found that the introduction of beech had begun in 1892, when V. V. Pashkevich laid English Park Station. We also revealed that from 1892 to 1987 the number of taxon beeches doubled, and to 1991 it increased 3 times. The quantitative description of beech plantings in the park is presented. The total number of tree species and beech forms is 845 pcs, among them the most common $F$. sylvatica amounts 633 trees, which accounts for the largest share in the structure of the park $74.9 \%$. Form diversity of $F$. sylvatica in the Dendrological Park prents 181 trees and accounts for 14 taxa. The largest concentrations of beech plantations are indicated as collecting area in the quarter N 1, exhibition area in the quarter N 14, large, clean plantations of F. sylvatica in the quarters N 4 and N 7, and alley plantations of F. sylvatica in the quarters N 19 and N 20. The age structure of species and forms of beech in the National Dendrological Park "Sofiyivka" is presented fairly widely. The tendency of decreasing the number of beech trees with increasing age is revealed. The mass fraction of 100 year old trees is $0.3 \%, 50$ years old trees $-4 \%$, 21 years old trees $-14.5 \%$. We estimated phytosanitary state of trees of beech monogarden as weakened (1st group). The possibility of spring attack of young plants of beech with aphids from the family Aleyrodidae Westwood was defined. We evaluated the quality of the beech trees in the plantations of the park as good. In the plantations of certain quarters an excessive compaction of the tree stand has been found, which reduces its quality to a satisfactory state. It is recommended to perform the thinning of the tree stand in clean plantations of F. sylvatica in the quarters N 4, 27 and 30. We propose landings of insufficiently presented forms of beech to be performed. On the basis of conducted research, a consolidated catalogue of monogarden species and forms of beech was created in the National Dendrological Park "Sofiyivka", where the localization and number of trees in the quarter, the dendrological and age structure of plantings, biometric indices, landing plan and sanitary condition of the tree stands are presented.

Keywords: beech planting; history; structure; tree stand quality; optimization. 